ISLAMIC BANKING: Jurnal Pemikiran dan Pengembangan Perbankan Syariah, Volume 7 Nomor 2 Edisi Februari 2022

\title{
COMPARISON ANALYSIS OF CONVENTIONAL ECONOMIC SYSTEMS AND ISLAMIC ECONOMY ON DEMAND CONCEPT
}

\author{
Meriyati \\ Sekolah Tinggi Ekonomi dan Bisnis Syariah (STEBIS) Indo Global Mandiri \\ Email: meri@stebisigm.ac.id \\ M. Nasyah Agus Saputra \\ IAI Qomaruddin Gresik \\ Email: m.nasyah.agus.saputra@gmail.com \\ Sarah Lutfiyah Nugraha \\ Prodi Ekonomi Syariah, Pascasarjana Universitas Islam Negeri Sunan Ampel Surabaya \\ Email:02040321027@student.uinsby.ac.id
}

\begin{abstract}
Economic activity will not be separated from the existence of a demand such as buying and selling. Based on the conventional economic system, the number of requests from buyers/consumers will affect the price of an item being sold. The demand concept will also not be separated from microeconomics. Humans often make purchase transactions based on mere desire so that the demand for an item becomes high. The problem is whether the factors that influence demand in the Islamic economic system are the same as in the conventional economic system. Therefore, in this study, we want to find out whether there are similarities or differences between the demand concept in the conventional economic system and the Islamic economic system. This research is a library research that seeks to analyze the comparison between the two economic systems related to the demand concept. Based on the research results, there are differences between the two systems related to the demand concept. Which is the Islamic economic theory which is based on the Qur'an and Hadith and the ijtihad of the scholars, the demand for an item or purchase is not based on desire alone, but is prioritized on things that are needed by humans.
\end{abstract}

Keywords: Comparison Analysis, Islamic Economic System, Conventional Economic System, Demand Concept.

\begin{abstract}
Abstrak
Aktivitas ekonomi tidak akan terlepas dengan adanya suatu permintaan seperti adanya jual beli. Berdasarkan sistem ekonomi konvensional, banyaknya permintaan dari pembeli/konsumen akan mempengaruhi harga suatu barang yang dijual. Teori permintaan juga tidak akan terlepas dengan mikro ekonomi. Manusia sering kali melakukan transaksi pembelian berdasarkan keinginan semata sehingga permintaan terhadap suatu barang menjadi tinggi. Permaslahannya
\end{abstract}


adalah apakah factor-faktor yang mempengaruhi permintaan dalam system ekonomi islam sama dengan system ekonomi konvensional. Oleh karena itu dalam penelitian ini ingin mengetahui apakah ada persamaan atau perbedaaan antara teori permintaan dalam sistem ekonomi konvesional dengan system ekonomi islam. Penelitian ini merupakan penelitian kepustakaan (library research) yang berusaha untuk menganalisi perbandingan antara dua system ekonomi tersebut terkait teori permintaan. Berdasarkan dari hasil penelitian, maka terdapat perbedaan antara kedua system tersebut terkait teori permintaan. Yang mana teori ekonomi Islam yang berlandaskan Al-Qur'an dan Hadist serta ijtihad para ulama, permintaan suatu barang atau pembelian tidak berdasarkan keinginan semata, melainkan lebih diutamakan pada hal-hal yang dibutuhkan oleh manusia.

Kata Kunci: Analisi Perbandingan, Sistem Ekonomi Islam, sistem Ekonomi Konvensional, Teori Permintaan

\section{Introduction}

The market meets demand and supply for one kind of goods/service. In the market, buyers and sellers bargain with each other to determine the price of various types of goods (Wulandari \& Zulqah, 2020). In economic analysis, the notion of the market is not limited to a certain place but includes an area, country, and even the international world. Individual behaviour in economic actors or what is done in the market is very influential in the concept of microeconomics. The individual determines the course of the market mechanism. The market mechanism is an interaction between producers and consumers between demand and supply (Solihin, 2019).

Islamic economics has a view related to the course of demand. Requests made by individuals have limitations by the needs that need to be fulfilled. This is based on the Qur'an, Hadith, and the ijtihad of the scholars (Afif, 2017).

Compared to conventional demand concept. Islamic demand concept discusses Muslims as economic actors who determine the value of demand and price movements of an item. Requests made must be based on needs, not mere desires, and must consider the benefit (Aravik, 2016). Islamic teachings require people to consume halal and good goods. Islamic rules forbid a Muslim to eat forbidden items, except in an emergency where it will affect the Muslim if the item is not eaten. In times of emergency, a Muslim is allowed to consume haram goods in moderation. In contrast to the teachings in the conventional economic system, Islamic teachings in this case are associated with the 
ISLAMIC BANKING: Jurnal Pemikiran dan Pengembangan Perbankan Syariah, Volume 7 Nomor 2 Edisi Februari 2022

Islamic economic system, people who have much money are not necessarily allowed to spend money to buy anything and whatever amount they want. Therefore, the budget constraint is not sufficient in limiting consumption. Another limitation that must be considered is that a Muslim is not excessive (israf), and must prioritize goodness (maslahah). Islam does not encourage the demand for an item to splendor, luxury, and waste (Kasdi, 2016). Based on this explanation, this study wants to analyze the similarities or differences between the two systems, namely between the conventional economic system and the Islamic economic system, especially regarding the demand concept.

\section{Research Methods}

This research is a library research. Literature research is carried out by reviewing the literature based on problems. In collecting data (primary data and secondary data) related to the object of research. The data comes from books related to research, research results, journals and other documents. Library research is a series of activities related to library data collection methods, reading and recording and processing research materials related to research topics (Zeid, 2014). This study uses a qualitative descriptive approach, in the form of collecting supporting data, and combining it from several sources and then comparing it with other sources. This research was conducted through the collection of journals and data collection on "demand concept" in the perspective of conventional economic systems and Islamic economics, which then attempted to compare the two systems. This is the focus of this research, so this research is very strong.

\section{Discussion}

\section{Demand Concept}

Demand can be interpreted as the number of goods demanded by consumers in a certain market at a certain price level at a certain income level. Demand is affected by the size of the price change. This is because the ratio of demand to price is inversely proportional, while the ratio of demand to supply is directly proportional. 
The law of demand is a law that explains the negative relationship between the price level and the quantity demanded. If the price of an item increases, the quantity demanded will be less, and if the price is lower, the quantity demanded will increase. In essence, the lower the price of goods, the more demand for goods, and the higher the price of goods, the less demand for goods (Fattach, 2017).

There is the law of cateris paribus in demand. Cateris Paribus means a law of demand applies if factors other than price do not change (considered constant/ cateris paribus) (Muflihin, 2019). The law of demand for halal goods is the same as the law of demand in economics in general, which is inversely proportional to the price. If the price increases, the demand for halal goods decreases, and vice versa with the assumption of cateris paribus (Gilarso, 2007).

There are factors in determining demand, namely (Haryanti, 2019):

1. The price of goods, an increase or decrease in the price of an item will affect the quantity demanded of an item

2. Prices of other goods that are closely related to the item, if an item is in scarcity, then the price of the item will increase, but the amount of demand can be different if there are similar items

3. Household income, income owned by the community certainly affects the goods to be sought or purchased so that it affects demand

4. The average income of the community, if the income distribution of the community is evenly distributed, the number of requests will also change

5. The taste of the community, if there is a change in an environment, it will change the taste or desire of an item from the community and affect demand

6. The number of residents, if the population increases, the number of requests made will increase.

In addition to demand factors, there are various kinds of demand, namely: (Mashuri, 2019):

1. Judging from the purchasing power of consumers, demand is grouped as follows:

a. Effective demand, is consumer demand for goods and services accompanied by purchasing power or ability to pay. 
ISLAMIC BANKING: Jurnal Pemikiran dan Pengembangan Perbankan Syariah, Volume 7 Nomor 2 Edisi Februari 2022

b. Potential demand, is consumer demand for goods and services that are not accompanied by purchasing power or only based on needs.

2. Judging from the real income of consumers, demand is grouped as follows:

a. Consumer demand, namely requests made by all members of society for goods and services to meet needs.

b. Demand for entrepreneurs starts from entrepreneurs trying to produce goods and services needed by consumers.

c. The government's request, starting with the government spending for the smooth running of the wheels of government, gives rise to the government's demand for goods and services.

d. Foreign demand is formed from requests from consumers, entrepreneurs, and governments of other countries so that it also affects domestic demand.

3. Judging from the number of consumer requests, requests are grouped as follows:

a. Individual requests, which are requests from someone to meet the needs of life, are different from one person to another, depending on income and education.

b. Market or collective demand, is a demand owned by the community as a whole at the same time.

\section{Functions in Demand}

The demand function explains the existence of an interrelated relationship between price and the amount of goods/services in consumer demand based on an undetermined price and time so that it means that the amount of an item or service that will be demanded depends on the high or low price that applies to the item and a certain time (Mashuri, 2019).

A list describes the relationship between prices and the quantity of an item demanded by consumers at the current price. The list is a list of requests (demand schedule). So from the demand function or demand schedule, a demand curve or demand curve can be drawn (Syamsudin \& Karya, 2018).

The demand function for an item in the Islamic perspective of demand can be written: the total quantity of goods $x$ demanded is $Q X=f(P X, P Y, T, I, E) . Q X$, the 
302

Meriyati, et.al, COMPARISON ANALYSIS OF CONVENTIONAL ECONOMIC

explanation is where $\mathrm{f}$ is income and product availability $\mathrm{x}, \mathrm{PX}$ is the price of an item with the symbol $\mathrm{x}, \mathrm{PY}$ is the price of an item $\mathrm{Y}, \mathrm{T}$ is an index of consumer tastes and preferences, I is an individual's ability to buy according to the income earned, $\mathrm{E}$ is an expectation from all consumers regarding a price in the future (Wibowo \& Supriadi, 2013).

The demand curve is a curve that presents the relationship of the price of an item (cateris paribus) to the quantity of an item that will be demanded from buyers. Therefore, the demand curve will change if there is a change in the price of an item (Haryanti, 2019).

A shift in the demand curve occurs from the lower left to the upper right and vice versa, indicating that the slope is positive. This curve occurs because of the relationship between demand and the price of goods (Febianti, 2014).

\section{Islamic Demand Concept}

Islam considers a commodity (goods or services) to be distinguished from halal and haram, so that not all goods or services can be consumed or used. Meanwhile, in conventional demand concept, all commodities of the same value can be consumed and used (Muhammad, 2004).

According to Ibn Taimiyah, the demand for an item is a desire for something described by the term raghbah fil al-syai, namely the number of goods requested. Demand in Islamic economics is the same as conventional economics, but there are limitations that Muslim individuals must consider in their desires.

Islam requires consuming a halal item again thoyyib. Islam forbids a Muslim from consuming haram goods except in an emergency if there is nothing to eat. In addition, Islamic teachings explain that people who have much sustenance are not allowed to spend their money as they wish. Therefore, there is a budget constraint to limit consumption. Another limitation that must be considered is that a Muslim should not be excessive (ishraf) and prioritize goodness (maslahah). Islam does not encourage the demand for an item with the aim of splendor, luxury, waste. Even Islam also orders those who have reached the nishab, to set aside from their budget to pay zakat, infaq, and shadaqah (Fattach, 2017). The demand function also takes into account maslahah, 
ISLAMIC BANKING: Jurnal Pemikiran dan Pengembangan Perbankan Syariah, Volume 7 Nomor 2 Edisi Februari 2022

by getting the maximum maslahah in consumption, consumers will achieve falah or welfare (Muhammad, 2004).

According to Al-Ghazali, demand concept explains the role of buying and selling activities and the emergence of market prices that fluctuate according to how strong demand and supply are. Al-Ghazali also describes a curve that shows the movement from the bottom left to the top right, namely the demand curve (Haryanti, 2019).

It is also explained in Surah Al-Maidah verses 87-88 about consuming halal goods in accordance with Islamic demand concept. "You who have believed, do not prohibit the good things which Allah has made lawful to you and do not transgress. Indeed, Allah does not like transgressors.”.

"And eat of what Allah has provided for you [which is] lawful and good. And fear Allah, in whom you are believers."

\section{Factors Affecting Demand in Islam}

According to Ibn Taimiyah in the book Majmu 'Fatawa there are several factors that affect the demand for an item, namely (Fattach, 2017):

1. People's desire or taste for an item that is different and always changing, if there is a taste or desire then there is a demand

2. The number of fans of an item. If the number of people who want an item increases, the price of the item will increase.

3. Buyer quality (al-mu'awid), income level is a quality characteristic of a buyer, the higher the income level, the higher the quality of people to buy

4. Weak or strong need for an item, if the need for an item is high, then the demand for that item is also high

5. Payment method (cash or installments), if the purchase of the item is a cash transaction, usually the demand can be higher

6. The number of transaction costs, if the transaction costs of an item are low, the demand will increase 
304

Meriyati, et.al, COMPARISON ANALYSIS OF CONVENTIONAL ECONOMIC

\section{Differences between Conventional Demand Concept and Islamic Demand Concept}

There are many similarities between conventional demand concept and Islamic demand concept. However, there are still fundamental differences between the two, namely (Fattach, 2017):

1. The sources of law used, the concept of Islamic demand using the legal sources of the Qur'an and Hadith, and the ijtihad of the scholars can be added. Whereas conventional demand concept is based on human thinking and only focuses on profit and materialism

2. The concept of Islamic demand separates commodities that are used halal and haram and can only consume and use halal commodities. Meanwhile, the conventional concept of demand allows all commodities

3. Islamic demand concept emphasizes the demand for a good or service on consumer needs. Meanwhile, conventional demand concept allows demand for consumer desires

4. The concept of Islamic demand must be based on maslahah or good, so that human life can achieve falah or prosperity and provision in the hereafter. Meanwhile, conventional demand concept does not consider aspects of goodness in life.

\section{CONCLUSION}

Based on the description of the discussion above, it can be concluded that Islam had long regulated the concept of demand before the conventional concept of demand existed because the sources used were directly from Allah SWT through the Qur'an, then equipped with Hadith and Ijtihad of the scholars. Therefore, Islamic demand concept has many similarities in its discussion with conventional demand concept. However, fundamental things distinguish it, such as the legal basis, the reasons for making requests based on needs are not mere desires. Islam made the concept of this Islamic demand to keep Muslims from being ishraf or excessive and to achieve falah or prosperity in life in this world and the hereafter. 
ISLAMIC BANKING: Jurnal Pemikiran dan Pengembangan Perbankan Syariah, Volume 7 Nomor 2 Edisi Februari 2022

\section{REFERENCES}

Afif, M. (2017). Teori Permintaan Dan Konsumsi Inter-Temporal Antara Islam Dan Konvensional. JES (Jurnal Ekonomi Syariah), 2(2).

Aravik, H. (2016). Ekonomi Islam: Konsep, Teori dan Aplikasi serta Pandangan Pemikiran Ekonomi Islam dari Abu Ubaid sampai al-Maududi. Empat Dua Intranspublishing.

Fattach, A. (2017). Teori Permintaan Dan Penawaran Dalam Ekonomi Islam. Jurnal Penelitian Ilmu Manajemen, 2(3).

Febianti, Y. N. (2014). Permintaan dalam Ekonomi Mikro. Edunomic Jurnal Pendidikan Ekonomi, 2(1).

Gilarso, T. (2007). Ilmu Ekonomi Mikro. Penerbit Kanisius.

Haryanti, N. (2019). Teori Permintaan dalam Perspektif Ekonomi Islam dan Konvensional. AKSY: Jurnal Ilmu Akuntansi Dan Bisnis Syariah, 1(2).

Kasdi, A. (2016). Permintaan Dan Penawaran Dalam Mempengaruhi Pasar (Studi Kasus di Pasar Bintoro Demak). BISNIS : Jurnal Bisnis Dan Manajemen Islam, 4(2).

Mashuri, M. (2019). Analisis Permintaan Dengan Pendekatan Maslahah. BALANCA: Jurnal Ekonomi Dan Bisnis Islam, 1(1).

Muflihin, M. D. (2019). Permintaan, Penawaran Dan Keseimbangan Harga Dalam Prespektif Ekonomi Mikro Islam. JES (Jurnal Ekonomi Syariah), 4(2).

Muhammad. (2004). Ekonomi Mikro Dalam Prespektif Ekonomi Islam. BPFE.

Solihin, B. (2019). Konsep Mekanisme Pasar dan Persaingan Harga Dalam Islam. AlMujaddid: Jurnal Ilmu-Ilmu Agama, 1(2).

Syamsudin, S., \& Karya, H. D. (2018). Mikro Ekonomi Untuk Manajemen. Rajawali Press.

Wibowo, S., \& Supriadi, D. (2013). Ekonomi Mikro Islam. Pustaka Setia.

Wulandari, C., \& Zulqah, K. A. (2020). Tinjauan Islam terhadap Mekanisme Pasar dan Penanganan Distorsinya. Journal of Islamic Economics and Finance Studies, l(1).

Zeid, M. (2014). Metode Penelitian kepustakaan ( Liberary Learning Methods). Yayasan Obor Indonesia. 
306 Meriyati, et.al, COMPARISON ANALYSIS OF CONVENTIONAL ECONOMIC.. 